\title{
Investigation of BRUCELLA SPP in milk and dairy products and lifespan of BRUCELLA MELITENSIS and BRUCELLA ABORTUS in kefir
}

\section{Süt ve süt ürüinlerinde BRUCELLA SPP'nin araştırilması ve BRUCELLA MELITENSIS ile BRUCELLA ABORTUS'un kefirde yaşamı}

\author{
Ayşe Hümeyra Taşkın Kafa, Zeynep Sümer
}

Sivas Cumhuriyet University, Faculty of Medicine, Department of Medical Microbiology, Sivas, Turkey
Corresponding author: Ayşe Hümeyra Taşkin Kafa, MD, Sivas Cumhuriyet University, Faculty of Medicine, Department of Medical Microbiology,
Sivas, Turkey
E-mail: ahtaskin@ cumhuriyet.edu.tr
Received/Accepted: October 24,2019/June 27,2020
Conflict of interest: There is not a conflict of interest.

\section{SUMMARY}

Brucellosis is common disease in our country and it is an important zoonotic infection that is up to date in terms of public health, animal industry and economic losses.

The aim of this study was to determine Brucella $\operatorname{IgG}$ positivity of raw milk and dairy products purchased non-packed and non-labelled. In this study, a total of 450 samples including 250 raw milk, 100 white cheese, 50 butter and 50 yoghurt samples were investigated by ELISA method for Brucella IgG positivity. $85(56.6 \%)$ of 150 raw milk samples obtained from Sivas province center and surrounding villages, 32 (32\%) of 100 raw milk samples obtained from the milk deliverers of Tokat province center and Reşadiye and Pazar districts of Tokat were detected positive for Brucella spp. $2(4 \%)$ of 50 white cheese samples collected in Sivas province center and $9(18 \%)$ of 50 white cheese samples collected in Tokat province center were positive for Brucella spp. None of the yoghurt and butter samples were positive for Brucella $\mathrm{IgG}$ antibodies

Additionally, in this study, the survival time of Brucella melitensis and Brucella abortus bacteria prepared in different bacterial density in kefir obtained from 3 different sources (A, B brand and homemade) were investigated. Bacteria in A and B brand kefir lived between 0-72 hours, while homemade kefir lived between 0-24 hours. No reproduction was observed at the end of the period. This study investigated Brucella Ig G positivity in milk and dairy products in Sivas and Tokat provinces and milk and dairy products may pose a risk for Brucellosis. Additionally, it was observed that Brucella could survive up to 3 days in probiotic fermented milk drink Kefir and the kefir suppresses Brucella growth.

Keywords: Brucella spp, milk and dairy products, kefir
Ayşe Hümeyra Taşkın Kafa

Zeynep Sümer

ORCID IDs of the authors: A.H.T.K. 0000-0002-7282-4928

Z.S. $0000-0002-1520-3359$

\section{ÖZET}

Bruselloz ülkemizde sık görülen bir hastalıktır ve halk sağlığı, hayvan endüstrisi ve ekonomik kayıplar yönünden güncelliğini koruyan önemli zoonotik bir enfeksiyondur. 
ELISA yöntemi ile incelendi. Sivas il merkezi ve çevre köylerinden elde edilen 150 çiğ süt örneğinin 85'i (\% 56,6), Tokat il merkezindeki sütçülerden ve Tokat'ın Reşadiye ve Pazar ilçelerinden elde edilen 100 çiğ süt örneğinin 32'si (\% 32) Brucella spp. yönünden pozitif bulunmuştur. Sivas il merkezinde toplanan 50 beyaz peynir örneğinden 2 'si $(\% 4)$ ve Tokat il merkezinde toplanan 50 beyaz peynir örneğinden 9'u (\% 18) Brucella spp. yönünden pozitif bulunmuştur. Yoğurt ve tereyağı numunelerinin hiçbirinde Brucella Ig G antikorları yönünden pozitiflik saptanamamıştır.

Ek olarak bu çalışmada 3 farklı kaynaktan (A, B markası ve ev yapımı) elde edilen kefirde farklı bakteri yoğunluğunda hazırlanan Brucella melitensis ve Brucella abortus bakterilerinin yaşam süreleri incelenmiştir. A ve B marka kefirlerde bakteriler 0-72 saat arasında yaşarken, ev yapımı kefir içerisinde 0-24 saat arasında yaşamıştır. Süre sonunda üreme gözlenmemiștir.

Bu çalışma Sivas ve Tokat illerinde süt ve süt ürünlerinde Brucella Ig G pozitifliği gösterilmiștir ve süt ve süt ürünleri Bruselloz için bir risk oluşturabilir. Ayrıca, probiyotik fermente süt içeceği kefirde Brucella'nın 3 güne kadar canlı kalabildiği ve kefirin Brucella’nın üremesini baskıladığı gösterilmiştir.

Anahtar sözcükler: Brucella spp, süt ve süt ürünleri, kefir

\section{INTRODUCTION}

Brucellosis, a zoonotic disease, cause facultative Gram-negative, intracellular Brucella bacteria, animals such as cattle, sheep, goats, pigs and dogs to settle in their genital organs and udders, complications such as offspring, infertility, mastitis, orchitis and arthritis. Brucellosis is present in more than 160 countries around the world and approximately 500,000 new human cases are reported annually ${ }^{1-3}$.

Brucella spp. can be directly transmitted from infected animals and contaminated tissues to humans via inhalation or through skin lesions particularly in endemic regions ${ }^{4,5}$. However, the most common way to be infected is ingestion of contaminated raw milk and dairy products in the world and in our country ${ }^{6,7}$. The vast majority of milk and dairy products produced in our country in very large quantities are produced from raw milk in unhygienic conditions, with primitive methods. While there is a decrease in disease incidence, our country is still among the endemic countries in terms of brucellosis ${ }^{8,9}$.

Brucella are Gram-negative coccobacilli (short rods) measuring about 0.6 to $1.5 \mu \mathrm{m}$ by $0.5-0.7 \mu \mathrm{m}$. They are non-sporing and non- encapsulated or flagella and, therefore, are non-motile ${ }^{10}$.

Brucellosis occurs as an acute and non-specific febrile disease. Classically, such symptoms may include fever, chills, generalized fatigue, headache, muscle aches (myalgias), loss of appetite, weight loss, night sweats, joint pain (arthralgia) and inflammation (arthritis), back pain, constipation. Because of the protean clinical signs of brucellosis, it is very important to take a detailed history and pay attention to epidemiological information. Care should be taken to determine whether the person is in contact with infected animals or whether milk and dairy products obtained from them are consumed $^{7,11}$.

Detection of Brucella bacteria in milk and dairy products is difficult and time consuming, therefore, currently the use of indirect methods has increased in diagnosis. In serological techniques, ELISA is widely used in various fields due to its high sensitivity and specifity, the ability to work with multiple samples at the same time, to obtain results in a short time and to be inexpensive ${ }^{12}$.

In this study, Brucella IgG antibodies were detected by ELISA method in raw milk and dairy products such as white cheese and butter and yoghurts in Sivas and some villages and in Tokat province center. Additionally, the lifespan of the Brucella bacterium was determined in the fermented milk drink kefir and the survival times of the two different brands of kefir offered for commercial consumption were compared with the home-made kefir.

\section{MATERIAL AND METHODS}

In this study, a total of 450 different samples consist of 250 raw milk, 100 white cheese, 50 yoghurts and 50 butter were tested for Brucella IgG positivity by ELISA. Distribution of milk and dairy products examined is summarized in Table 1.

$100 \mathrm{ml}$ of milk samples, $20 \mathrm{gr}$ of white cheese, butter and yogurt samples were taken into sterile containers and stored in the freezer at $-20^{\circ} \mathrm{C}$ until ELISA test. 
Table 1: Distribution of milk and dairy products examined for Brucella IgG by ELISA

\begin{tabular}{|l|c|c|c|c|c|}
\hline Locality & Raw Milk & White Cheese & Yoghurts & Butter & Total \\
\hline Sivas Province & 150 & 50 & 25 & 25 & 250 \\
\hline Tokat Province & 26 & 32 & 25 & 25 & 108 \\
\hline Reşadiye & 50 & 18 & - & - & 68 \\
\hline Pazar & 24 & - & - & - & 24 \\
\hline Total & $\mathbf{2 5 0}$ & $\mathbf{1 0 0}$ & $\mathbf{5 0}$ & $\mathbf{5 0}$ & $\mathbf{4 5 0}$ \\
\hline
\end{tabular}

Pathogen bacteria species inoculated into kefir samples to investigate the survival of Brucella bacteria in kefir; B. abortus (RSCC 279) and $B$. mellitensis (RSCC 310) strains obtained from Refik Saydam National Type Culture Collection

\section{Preparation of samples for ELISA and conducting the experiment}

The milk samples were processed directly and the yoghurt samples were homogenized in $10 \mathrm{~g} / 30 \mathrm{ml}$ of sterile physiological saline. Samples of cheese and butter were homogenized with blender in $10 \mathrm{~g}$ / $200 \mathrm{ml}$ sterile PBS (Phosphate Buffered Saline) and placed in eppendorf tubes. Institut Pourquier (France) brand Brucella IgG-ELISA Kit was used for the ELISA test. All samples were tested for Brucella IgG positivity according to the procedure indicated in the kit. The results were calculated according to the manufacturer's recommendations.

\section{Investigation of Survival of Brucella Bacteria in Kefir}

\section{Preparation of Kefir Samples}

In this research, three different kefir prepared from pasteurized milk were studied. One of the kefirs was produced from kefir grains, the other two were kefirs available for commercial consumption.

Pasteurized milk was taken into $1000 \mathrm{ml}$ sterile container, 15-20 gr of kefir grains were added and mixed thoroughly and the lid of the container was closed and incubated for 24 hours at ambient temperature of $20-25^{\circ} \mathrm{C}$. The kefir was passed through a plastic sieve placed on a container to separate the grains. Prepared and commercially purchased kefir were distributed in $20 \mathrm{ml}$ each in $100 \mathrm{ml}$ sterile containers. No treatment was performed on 2 samples per $3 \mathrm{kefir}$ and removed as a control group. B. melitensis and B. abortus were used as pathogenic bacteria for inoculation.

\section{Experimental Procedure}

In this study, B. melitensis and B. abortus bacteria produced in Serum Dextrose Agar (SDA) were added to 3 different kefir samples of $20 \mathrm{ml}$ each from suspensions of different bacterial concentrations to be $100 \mu \mathrm{l}$ each. Then the samples were incubated at $37^{\circ} \mathrm{C}$. At the end of $24,48,72$, 96 and 120 hours, $50 \mu 1$ of each kefir sample were inoculated SDA media and incubated at $37^{\circ} \mathrm{C}$.

At the end of this period, bacterial growth in SDA was studied individually. Bacterial morphology was evaluated by gram staining from each different colonies. Gram-negative, small coccobacilli, cocoid morphology colonies were identified with polyvalent antiserum specific to Brucella species (B. abortus, B. suis, B. melitensis).

Statistical analysis of the study was performed using IBM SPSS Statistic 22.0 (IBM Co., Armonk, $\mathrm{NY}$, USA). Chi-square $\left(\mathrm{x}^{2}\right)$ test was used to compare the data. Values of $\mathrm{P} \leq 0.05$ were considered statistically significant.

\section{RESULTS}

\section{ELISA Test Results in Milk and Dairy Products}

$117(46.8 \%)$ of 250 raw milk samples were positive for Brucella spp. 85 (56.6 \%) of 150 raw milk samples taken from Sivas province center and surrounding villages and 32 (32\%) of 100 raw milk samples obtained from Tokat province center milk deliverers and Reşadiye and Pazar districts were found to be positive for Brucella spp. (Table 1). The difference between provinces was statistically significant $(\mathrm{p}=0.000)$. 
Table 2: Occurrence of Brucella spp. among raw milk samples by ELISA*

\begin{tabular}{|l|c|c|}
\hline Sivas Province and Villages & Total number (\%) & Number of positive (\%) \\
\hline Sivas Province & $13(5,2)$ & $11(4,4)$ \\
\hline Sivas Surrounding Villages & $137(54,8)$ & $74(29,6)$ \\
\hline Tokat Province and Districts & & $7(2,8)$ \\
\hline Tokat Province & $26(10,4)$ & $16(6,4)$ \\
\hline Reşadiye & $50(20)$ & $9(3,6)$ \\
\hline Pazar & $24(9,6)$ & $\mathbf{1 1 7}(\mathbf{4 6 , 8})$ \\
\hline Total & $\mathbf{2 5 0}(\mathbf{1 0 0})$ & \\
\hline
\end{tabular}

*ELISA=Enzyme-linked immunosorbent assay

Additionally, $11(11 \%)$ of 100 cheese samples were positive for Brucella Ig G. Brucella seropositivity in white cheeses collected from Sivas, Tokat province and Reşadiye districts were $4 \%, 12.5 \%$ and $27.7 \%$ respectively (Table 2 ). The difference between the results obtained from Sivas, Tokat and Reşadiye was statistically significant ( $\mathrm{p}$ $=0.02$ ). None of the yoghurt and butter samples were positive for Brucella $\mathrm{IgG}$ antibodies.

Table 3: Occurrence of Brucella spp among white cheese samples by ELISA

\begin{tabular}{|l|c|c|}
\hline Locality & Total number (\%) & Number of positive (\%) \\
\hline Sivas Province & $50(50)$ & $2(4)$ \\
\hline $\begin{array}{l}\text { Tokat } \\
\text { Province }\end{array}$ & $32(32)$ & $4(12,5)$ \\
\hline Reşadiye & $18(18)$ & $5(27,7)$ \\
\hline Total & $\mathbf{1 0 0}$ & $\mathbf{1 1}(\mathbf{1 1})$ \\
\hline
\end{tabular}

\section{B. melitensis and B. abortus bacteria in different kefir samples to determine the survival of the results of the study}

As a result of this study; B. abortus (RSCC 279) and B. mellitensis (RSCC 310) bacteria in A and B brand kefirs purchased in markets, $0.9 \times 10^{7}, 1.2$ $\mathrm{x} 10^{7}$ and $1.5 \times 10^{7}$ bacteria densities while it can reproduce within of 24-72 hours, reproduction has not been observed at the end of 72 hours. In the homemade kefir, these three bacteria survived in the first 0-24 hours, but no growth was observed after 24 hours.

\section{DISCUSSION}

Brucellosis remains the commonest and important zoonotic disease worldwide which is transmitted from animals to humans, has been a major health problem with more than 500000 new cases annually. The main source of contamination for brucellosis is unpasteurized milk and dairy products (fresh cheese, cream, butter, etc.) consumption. The majority of dairy products are produced from raw milk in unhygienic conditions, primitive methods, and thus the disease remains a serious health problem in developing countries and in our country ${ }^{13-14}$.

In our study, 117 (46.8\%) of 250 raw milk samples were positive for Brucella spp. 85 (56.6\%) of 150 raw milk samples taken from Sivas province center and surrounding villages and $32(32 \%)$ of 100 raw milk samples obtained from Tokat province center milk deliverers and Reşadiye and Pazar districts were found to be positive for Brucella spp. The difference between these provinces was statistically significant $(p=0.000, p<0.05)$. It is thought that Brucella seropositivity is higher in the milk samples collected from Sivas province than Tokat, the distribution of samples is mostly belong to villages, it is thought that the animals in the villages may carry a higher risk of brucellosis than living in the province. One of the reasons for the occurrence of Brucella Ig G in nearly half of the 
raw milk used in our study ( $46.8 \%$ ) may be due to the fact that the organism localizes in the supramammary lymph nodes and mammary glands in the of $80 \%$ of the infected animals and pass the infection agent into the milk during lactation periodically or intermittently ${ }^{15}$. It has been shown in studies that $1 \%$ and $40 \%$ isolations of Brucella spp. were from raw milk in our country and other countries, ${ }^{16-19}$.

It has been shown in studies that $0 \%$ and $20.5 \%$ isolations of Brucella spp. were from cheese in our country ${ }^{20-24}$. In our study, 11 (11\%) of 100 cheese samples were positive for Brucella Ig G. Brucella seropositivity in white cheeses collected from Sivas, Tokat province and Reşadiye districts were $4 \%, 12.5 \%$ and $27.7 \%$ respectively. The difference between the provinces was statistically significant $(\mathrm{p}=0.02, \mathrm{p}<0.05)$. Cheese samples obtained from Tokat province showed higher positivity in terms of Brucella Ig G compared to Sivas due to the unpacked cheeses purchased in the markets and from the Reşadiye.

Fermented dairy products such as cheese made from raw milk because it is difficult and time consuming to make the cheese from the milk that has been processed such as boiling and pasteurization. It is thought that there will be a decrease in the amount and flavor of the cheese that will be obtained after boiling. The majority of the cheeses from Sivas were sourced from markets and delis. Cheeses purchased in such places are offered for sale with very different brands. These companies must comply with certain criteria in their production processes and meet the necessary requirements, especially in relation to pasteurization of milk. As a result, cheeses produced in accordance with quality standards reach the consumer in a healthy way. Therefore, this difference in the cheese population is reflected in the results.

None of the butter samples were positive for Brucella IgG. The reason is that the butter is not prepared from the milk of the infected animals, boiling the milk, pasteurizing or churning the yogurt to obtain butter. However, considering the fact that butter can be produced from raw and inadequately treated milk, the possibility of a health risk for brucellosis should always be considered. In the study of Taşç1 et al. (2009) In butter, cream and whipped cream cakes offered for consumption in Ankara. They did not isolate the Brucella spp. in any of the 135 samples examined.

None of the yoghurt samples were positive for Brucella $\operatorname{IgG}$. The reason is that lactic acid bacteria in yogurt, which is fermented food, inhibit the growth of many pathogenic microorganisms. Lactic acid produced by lactic acid bacteria against many acid-sensitive bacteria, Brucella spp. These bacteria also have show bacteriostatic effect. Additionally, heat treatment of milk in the production process of yogurt is thought to prevent the growth of these bacteria.

Additionally, in this study, the survival time of B.melitensis and B.abortus bacteria in kefir, a valuable, complex probiotic fermented dairy product, was determined. Bacteria survive between 0- 72 hour in A and B brand kefir, and they cannot grow as from 72 hour. Bacteria in homemade kefir survive between 0-24 hour and cannot grow as from 24 hours. No significant difference was observed between the two bacterial species in terms of survival. In homemade kefir, microflora is the dominant species Candida spp. whereas lactic acid bacteria predominate in other kefir. Differences in the survival of pathogens in homemade kefir and kefir belonging to two different brands were determined by lactic acid bacteria and Candida spp. may be due to the difference in metabolic products. The metabolic products exhibits antimicrobial activity by inhibiting the growth of patogen bacteria. Kefir antimicrobial activity is associated with the production of organic acids, peptides (bacteriocins), carbon dioxide, hydrogen peroxide, ethanol and diacetyl. Ito et al. (2003) in their study Lactobacillus lactis subsp. lactis with $\mathrm{H}_{2} \mathrm{O}_{2}$ formation Escherichia coli, Yersinia enterocolitica, Listeria that the inhibitory effect on species. They also found that $\mathrm{pH}$ plays a negative role in the development of the species mentioned 26.

Chifiriuc et al. (2011) indicated that all milk fermented with kefir grains had antimicrobial effect against Bacillus subtilis, Staphylococcus aureus, E. coli, Enterococcus faecalis and Salmonella enteritidis. Rodrigues et al. (2005) reported the potential antimicrobial activity of the polysaccharide kefiran against bacteria and $C$. albicans $^{27,28}$.

\section{CONCLUSION}

As a result, in the present study was showed Brucella Ig G positivity in milk and dairy products in Sivas and Tokat provinces and raw milk and dairy products may pose a risk for Brucellosis. Furthermore, it was observed that kefir suppresses Brucella bacteria growth.

Brucellosis, which is one of the important zoonoses, is very common among sensitive animals and humans in Turkey. Thus successful, meticulous and continuous implementation of 
disease control programs should be carried out in the eradication of brucellosis. Further research focusing on the isolation of Brucella is required to determine regional disease rates and to obtain a comprehensive understanding of the Brucella spp.

Kefir, which is another research topic we have studied, has been shown many important properties such as antimutagenic, antioxidant, antimicrobial in animal studies. Considering the increasing consumption of kefir in our country, studies on this subject will provide valuable data to the literature as well as guiding for industrial production.

\section{REFERENCES}

1. Mirnejad R, Jazi FM, Mostafaei S, Sedighi M. Epidemiology of brucellosis in Iran: a comprehensive systematic review and metaanalysis study Microb. Pathog. 2017; 109, 23947

2. Dean AS, Crump L, Greter H, Schelling E, Zinsstag J. Global burden of human brucellosis: a systematic review of disease frequency. PLoS Negl. Trop. Dis. 2012; 6 (10).

3. Mathew C, Stokstad M, Johansen TB, Godfroid $\mathrm{J}$ et al. First isolation, identification, phenotypic and genotypic characterization of Brucella abortus biovar 3 from dairy cattle in Tanzania, BMC Veterinary Research. 2015; 11:156

4. Rowe MT. Brucella - problems with dairy products. Encyclopedia of food microbiology. 2014; 340-3

5. Musallam II, Abo-Shehada MN, Hegazy YM, Holt HR, Guitian FJ. Guitian Systematic review of brucellosis in the Middle East: disease frequency in ruminants and humans and risk factors for human infection Epidemiol. Infect. 2016;144 (4), 671-85.

6. Tekin R, Karakoç ZÇ, Demirpençe Ö et al. Retrospective analysis of 286 brucellosis cases in the southeast of Turkey. 2012; J Clin Exp Invest. 2012; 3:335-9.

7. Guler S, Kokoglu OF, Ucmak H et al. Human brucellosis in Turkey: different clinical presentations. J Infect Dev Ctries. 2014; 8:5818.

8. Altun SK, Yiğin A, Gürbilek SE et al. An enzyme-linked immunosorbent assay for brucella specific antibody and real-time PCR for detecting Brucella spp. in milk and cheese in Şanliurfa, Turkey. Pak Vet J. 2017; 37(1): $39-42$.

9. Ünsal A, Alpat A, Tözün M, Arslantaş D, Tırpan K. Sivrihisar'da (Eskişehir) bruselloz yaygınlığı. Türk Mikrobiyol Cem Derg. 2007; 37(1): 19-25.

10. Alton GG, Forsyth JRL. Chapter 28 Brucella, Medical Microbiology. 4th edition. Baron S, editor. Galveston (TX): University of Texas Medical Branch at Galveston; 1996.

11. Franco MP, Mulder M, Gilman RH, Smits HL. Human brucellosis. Lancet Infect Dis. 2007;7(12):775-86.

12. Moreno E, Moriyo I. The Genus Brucella. Dworkin, M., Falkow, S., Rosenberg, E., Schleifer, K., H., Stackebrandt (Ed.) Third Edition, A Handbook on the Biology of Bacteria; Proteobacteria: Alpha and beta Subclasses, Chapter 3.1.16, 2006; 5: 315-456.

13. Godfroid J. Brucellosis in livestock and wildlife: zoonotic diseases without pandemic potential in need of innovative one health approaches. Arch Public Health. 2017; 75: 34

14. Yüce A, Çavuş SA. Türkiye'de Brusellozis: Genel Bakış. Klimik Dergisi. 2006; 19 (3) : 8797.

15. Hamdy MER, Amin AS. Detection of Brucella species in the milk of infected cattle, sheep, goats and camels by PCR. Vet J. 2002; 163(3): 299-305.

16. Rock KT, Mugizi DR, Ståhl K, Magnusson U, Boqvist $\mathrm{S}$. The milk delivery chain and presence of Brucella spp. antibodies in bulk milk in Uganda. Trop Anim Health Prod. 2016; 48:985-94

17. Wareth G, Melzer F, Elschner MC, Neubauer $\mathrm{H}$, Roesler U. Detection of Brucella melitensis in bovine milk and milk products from apparently healthy animals in Egypt by realtime PCR. J Infect Dev Ctries. 2014; 8(10):1339-43

18. Adıgüzel A, Güllüce M, Algur ÖF. Erzurum'a Bağlı Bazı Köylerden Toplanan Süt Örneklerinde Brucella abortus Antikorlarının ELISA ile Araştırılması. İnfeksiyon Dergisi. 2004;18(2) :187-91.

19. Türütoğlu H, Mutluer M, Uysal Y. Burdur Yöresinde Toplanan Sütlerin Brucella İnfeksiyonu Yönünden Araştırılması. Turk J. Vet Anim Sci. 2003;27: 1003-9.

20. Karadal F, Onmaz NE, Bağcı C. Niğde ilinde satışa sunulan koyun-keçi sütü ve peynirlerinde Brucella melitensis ve biyotiplerinin araştırılması. Erciyes Üniv Vet Fak Derg. 2016; 13(2):101-8.

21. Kalender H, Özcan C, Arslan N. Taze tulum peynirlerinden Brucella izolasyonu, Türk Mikrobiyal Cem. Derg. 2001; 31: 184-6.

22. Ataş M, Poyraz Ö, Alim A, Ataş AD, Çelik A. Sivas İl Merkezinde Satışa Sunulan Taze ve Salamura Beyaz Peynirlerin Brucella Bakterileri Yönünden İncelenmesi. Türk Hijyen ve Deneysel Biyoloji Dergisi. 2007; 64 (2): 914. 
23. Alim A, Tomul DZ. Sivas İl Merkezindeki Semt Pazarlarında Satılan Taze Peynirlerin Brucella Yönünden Araştırılması. Mikrobiyol Bült. 2005; 39(2): 219-223.

24. Erdoğdu S, Abay S, Aydın F. Çiğ Süt ve Peynirlerden Brucella spp. İzolasyonu ve Elde Edilen İzolatların Fenotipik ve Moleküler Yöntemler ile Biyotiplendirilmesi Erciyes Üniv Vet Fak Derg. 2018; 15(2): 94-102

25. 25-Taşçı F, Kaymaz Ş. Ankara'da Tüketime Sunulan Mutfaklık Tereyağı, Krema ve Krem Şantili Pastaların Brucella spp. Yönünden İncelenmesi. Firat Üniversitesi, Sağ. Bil. Vet. Derg. 2009; 23(1):05-08.
26. Ito A, Sato $\mathrm{Y}$, Kudo S. The Screening of Hydrogen Peroxide-Producing Lactic Acid Bacteria and Their Application to Inactivating Psychrotrophic Food-Borne Pathogens. Curr Microbiol. 2003; 47(3):231-6.

27. Chifiriuc MC, Cioaca AB, Lazar V. In vitro assay of the antimicrobial activity of kephir against bacterial and fungal strains. Anaerobe. 2011;17:433-435.

28. Rodrigues KL, Caputo LR, Carvalho JC, Evangelista J, Schneedorf JM. Antimicrobial and healing activity of kefir and kefiran extract. Int J Antimicrob Agents. 2005;25:404-408. 